\title{
Does Blended Learning Improve the Academic Achievement of Undergraduate Students in the Mathematics Course?: A Case Study in Higher Education
}

\author{
Najeh Rajeh Alsalhi ${ }^{1,2^{*}}$, Sami Al-Qatawneh ${ }^{1,2}$, Mohd. Eltahir $^{1,2}$, Khitam Aqel ${ }^{2}$ \\ ${ }^{1}$ College of Humanities and Sciences, Ajman University, Ajman, UNITED ARAB EMIRATES \\ ${ }^{2}$ Nonlinear Dynamics Research Center (NDRC), Ajman University, Ajman, UNITED ARAB EMIRATES
}

Received 21 September 2020 - Accepted 3 March 2021

\begin{abstract}
The study aimed to identify the impact of utilizing blended learning in teaching mathematics (MTH121) course on the achievement of undergraduate learners at Ajman University. The researchers followed the quasi-experimental approach. The sample of the study consisted of (196) males and females split into two control and empiric groups. The empirical group was taught using the blended learning method and the number of its students reached (99), while the other group is the control group studied in the usual conventional method, and its students reached (97) students. The study used an achievement exam in addition. The study found that there were significantly important variations in the achievement exam among the empiric and control groups for the benefit of the empirical group.
\end{abstract}

Keywords: blended learning, traditional learning, mathematics course, academic achievement, higher education

\section{INTRODUCTION}

Current twenty-first-century society faces many changes in all areas of life, including the educational field (Almaiah, Al-Khasawneh, \& Althunibat, 2020; Malik, 2018; Meyer \& Norman, 2020; Rahman, Singh, \& Pandian, 2018; Stuchlikova, 2016; Velle, 2020). Emphasis in the field of education has moved to active learning for students, which is defined as mentally active learning that keeps students engaged, and where the instructor or teacher can select the preferred method of teaching style based on the student's needs, instead of merely transferring information, which means concentrating on the quality of education (Fitzsimons, 2014; Marina \& Tatjana, 2020; Rocher, 2018). According to constructivist theories, the learner builds their own knowledge through social interaction with others and the environment, and builds new knowledge based on previous knowledge and experience (Ayse, 2008). Accordingly, educational institutions have begun to seek quality teaching methods that aim to create active and positive students. One of the ways in which teachers are being guided to achieve such educational outcomes is through mixing traditional education with e-learning with its multiple styles, and with technological and electronic innovations inside the classroom and outside it (United Nations, 2019). Therefore, the focus is on the simultaneous application of two types of education, traditional and e-learning (Crawford and Jenkins, 2017).

Yilmaz and Orhan (2010) pointed out that to achieve the goals of constructivist theory, a set of constructivist learning strategies have emerged that link technology to learning in accordance with structural philosophy and call for cooperative, collaborative learning and social interaction through which learners build their own knowledge. Thus, the philosophy of blended learning emerged, which is an extension of classroom instruction over the internet. It provides educational institutions, such as universities and schools, with modern teaching methods and approaches to addressing the challenges they face and interesting new learning methods (Mula, 2015).

A number of researchers have reported that blended learning has emerged as a natural development of elearning, as e-learning combines and integrates elearning with traditional face-to-face classroom learning in a single learning model to gain the benefits and advantages of each and to achieve the desired objectives (Graham, 2013; Power, 2008; Shaaruddin \& Mohamad,

(c) 2021 by the authors; licensee Modestum. This article is an open access article distributed under the terms and conditions of the Creative Commons Attribution License (http://creativecommons.org/licenses/by/4.0/).

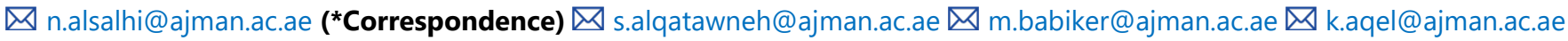




\section{Contribution to the literature}

- This study investigates the impact of using blended learning in the teaching of a mathematics course on students' achievement at Ajman University, as an example of higher education institutions.

- The current study is in line with the directives of higher education institutions all over the world to improve the methods and techniques of university teaching in line with the requirements of the twentyfirst century.

- This study also provides a modest addition to the literature about education in methods of teaching Mathematics courses, and will encourage faculty members to employ blended learning during the teaching process.

2017; Ustun \& Tracey, 2020; Wang, 2010). In reality, elearning or traditional education does not imply an either/or situation, where the adoption of one necessitates the complete cancellation of the other; it is a combination of both (Alzahrani \& Toole, 2017; Elfaki, Abdulraheem, \& Abdulrahim, 2019; Graham, 2013; Moskal, Dziuban, \& Hartman, 2012; Sicilia, 2018; Wright, 2017). For example, blended learning is described as one of the forms of e-learning in which e-learning is 'blended' with conventional education in one system (Sarıtepeci \& Çakır, 2015; Shang, \& Liu, 2018). In blended learning, e-learning tools, whether computer-based or network-based, are used for lessons, lectures, and training sessions, which are often conducted in realworld classrooms with the ability to connect to one another (Adiguzel, Kamit, \& Ertas, 2020; Yeou, 2016). Bervell, Nyagorme, and Arkorful (2020), pointed out that the Learning Management System (LMS) is one of the technologies that made blended learning possible in distance learning. Trapp (2006) and Velerie (2005) have described blended learning as the broad integration of electronic teaching media with traditional methods of teaching. Francis and Shannon (2013) highlighted the significance of blended learning, which integrates the benefits of conventional teacher-led learning and the advantages of information technology (IT), for the development of educational programs that include the content of the prepared scientific subject, web-based instruction, workshops, conferences, and live sessions with teachers on the web. According to Huang (2002), a number of educators and experts believe that blended education may encounter resistance that hinders its success if it violates the course of the educational process. The teacher and the learner represent the basic components, in addition to the educational curriculum (Devlin \& Samarawickrema, 2010). Thus, in order for success to be achieved, the teacher must be able to use modern education techniques, and students must be skilled in the use of computers, the internet, and e-mail which help transfer this education to classrooms (Bunatovich \& Khidayevich, 2020). According to Sahni (2019) and Alammary, Sheard and Carbone (2014), blended learning may be one of the most effective new approaches for university education to familiarize the learner with continuous learning, enabling the learner to educate themselves and enrich their information. This is the case because the goal of university education is to develop critical and creative thinking skills, and to provide students with methods of generating knowledge, and to enable them to continue their learning in the future (Oweis, 2018; Tongchai, 2016). Furthermore, ElSayary (2021), in the study Using a Reflective Practice Model to Teach STEM Education in a Blended Learning Environment, illustrated that teachers' perceptions and practices about learning and skills needed in the future will be different from the preCOVID-19 era.

Eduviews (2009) and Tucker (2012) pointed out that blended learning can be implemented in the education sector using a diverse range of models. Figure 1 summarizes these models. In educational institutions in the United Arab Emirates, e-learning has been introduced to education in universities through the computerization of education (Abouchedid \& Eid, 2004; Snoussi, 2019; Vrazalic, MacGregor, Behl, \& Fitzgerald, 2009). This has been done via the introduction of elements of development based on modern technological methods in the educational system, as well as electronic networks, and the preparation of classrooms and virtual laboratories, in order to integrate these programs with the traditional system to improve learning outcomes (Kemp, 2013). Therefore, blended learning has been incorporated into the classroom, making the process of education and the achievement of educational goals easier for both teachers and students in Emirate Universities. Through the availability of these capabilities and services in universities, Each faculty member can use them with their students. This introduction of the potential for extensive application of blended learning raises the need for research into its effectiveness in this specific context. It is this consideration to which the current study responds.

Numerous studies (discussed and referenced later in this and subsequent paragraphs) have highlighted the significance of blended learning in the education sector. The findings of these studies have shown the effectiveness of blended learning, which has culminated in many educational benefits in the fields of academic, mental, psychomotor, and emotional skills. In addition, the findings of these studies have also shown that enhanced blended learning is increasingly developing 


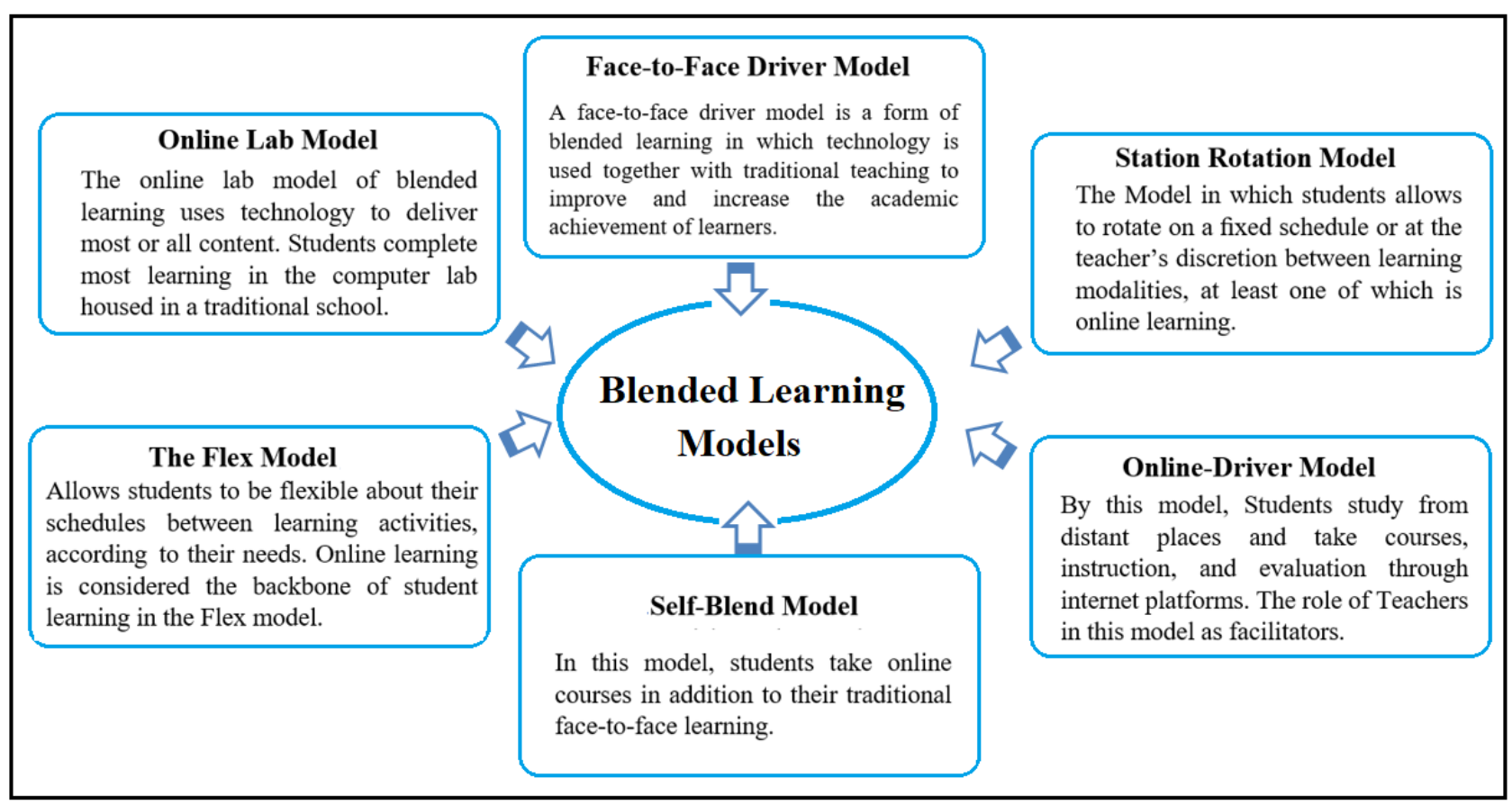

Figure 1. Blended learning models (Eduviews, 2009; Tucker, 2012)

and improving pedagogy and producing fundamental paradigm shifts, but teachers' competencies in blended learning remain uncertain (Alammary, Sheard \& Carbone, 2014; Ameloot \& Schellens, 2018; Dziuban et al., 2018; Eryilmaz, 2015; Fazal \& Bryant, 2019; Graham, 2013; Kintu et al., 2017; Mondal, Majumder, \& Mandal, 2019; Sahni, 2019).

Several studies have highlighted the significance of blended learning in improving academic achievement, increasing motivation, and developing positive attitudes for learning mathematics (Al-Madani, 2015; Ameloot \& Schellens, 2018; Awodeyi, Akpan, \& Udo, 2014; Ceylan \& Kesici, 2017; Fazal \& Bryant, 2019; Kazu \& Demirkol, 2014; Lin, Tseng, \& Chiang, 2017; Manguire, 2005; Naidoo, Naidoo, \& Ramdass, 2017; Pechenkina, Scardamaglia, \& Gregory, 2018; Seage \& Türegün, 2020; Yilmaz \& Orhan, 2010). The results of these studies have revealed the role and significance of blended learning in improving students' achievement, increasing their motivation, and also developing their positive attitudes toward learning mathematics. They have also confirmed the acceptance of blended learning in universities and schools, as a result of its perceptions as an effective approach for their learning.

On the other hand, however, there are some studies that found that post-test scores did not show a significant difference between the experimental group and the control group, which indicates that blended learning did not show much effectiveness over traditional teaching methods (Klimova, 2017; Yusoff, Yusoff, \& Md Noh, 2017). In addition, the results of the study conducted by Kwak, Menezes, and Sherwood (2015) revealed that blended learning has no effect on student achievement if learning is non-cumulative, and only affects the performance on assessments associated with the blended learning materials.

\section{Research Purpose}

Technology has become one of the vital educational methods associated with the learning and instruction processes, educational curricula, and assessments of the educational system. Thus, the current study seeks to examine the effectiveness of using blended learning in a mathematics course (MTH121), in terms of the achievement of undergraduate learners at an engineering college at Ajman University.

\section{Research Questions}

The questions guiding this study were formulated as follows:

1. Is there a significant difference between the control group and experimental group students' mean scores on the post-test focusing on the mathematics course topics that they learned?

2. Does the academic achievement of experimental group students vary by gender, students' academic evaluation (GPA), and computer skills?

\section{SIGNIFICANCE OF THE STUDY}

1- The study responds to calls for research on teaching methods and strategies focused on constructivist theories, especially in mathematics and science.

2- This study is in line with the directives of the UAE Ministry of Higher Education to upgrade university teaching methods and techniques in 


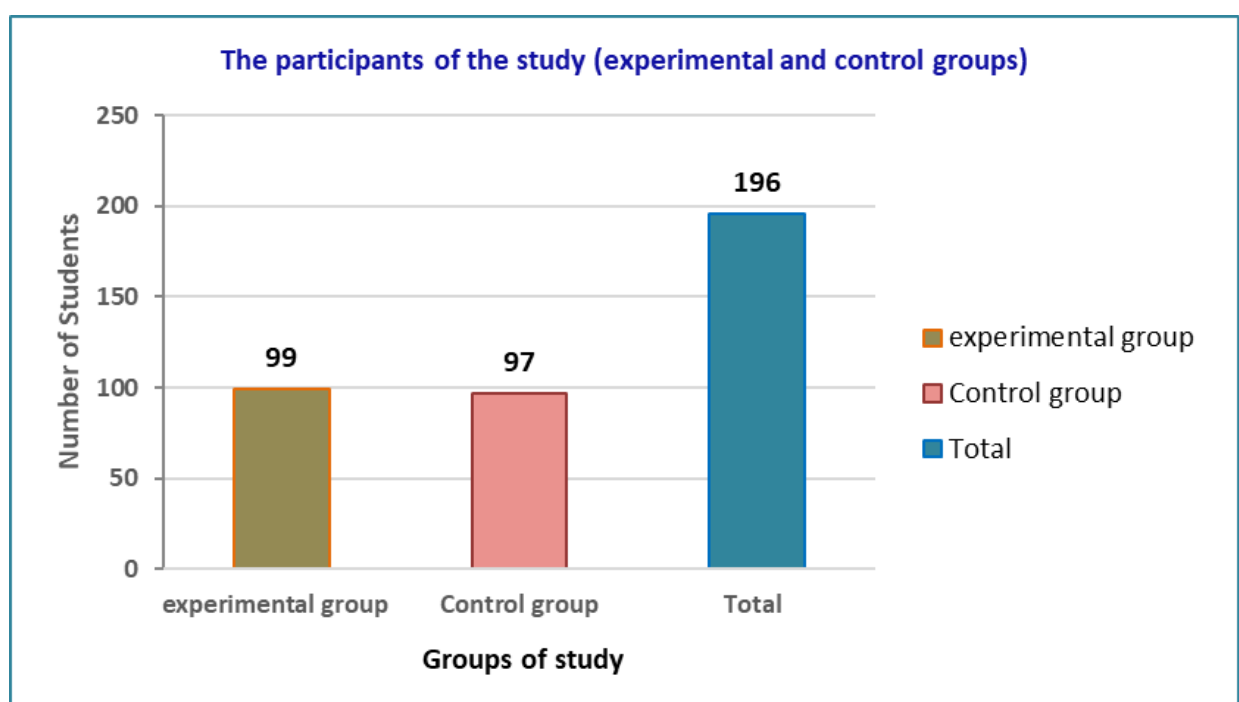

Figure 2. Participants of the study

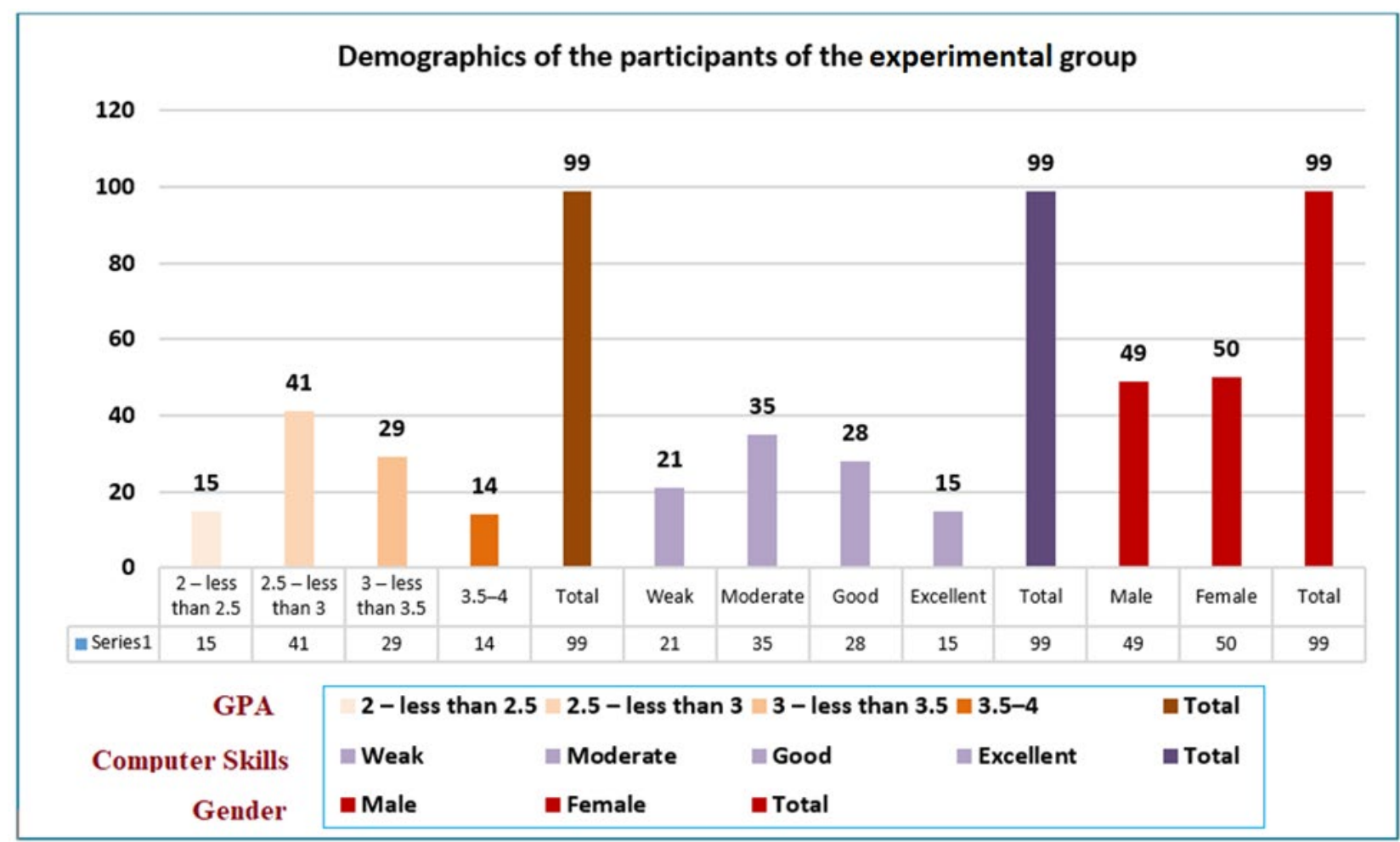

Figure 3. Demographics of the participants of the experimental group

line with the requirements of the twenty-first century.

\section{METHODOLOGY}

\section{Participants}

Participants in this study were 196 undergraduate students of an engineering college at Ajman University, enrolled in a mathematics course (MTH121), which is a mandatory course for all students of the Engineering and Information Technology College at Ajman University. They were split into an experimental group of 99 students and a control group of 97 students (see Figures
2). Figure 3 illustrates the demographics of the experimental group.

\section{Study Approach}

Due to its appropriateness for the study's objectives, a quasi-experimental approach was applied. In the current study, the researchers used two groups of students: an experimental group $(\mathrm{n}=99)$ and a control group ( $\mathrm{n}=97)$. The topics of the mathematics course (Course Code: MTH121) were taught to the students in the control group using conventional teaching, while in the experimental group the students were taught the same topics of the mathematics course by using blended 
Table 1. The learning topics of mathematics course (MTH121)

\begin{tabular}{lc}
\hline Mathematics (MTH12) Topics & Week \\
\hline Limits of functions, theorems about limits. & 1 \\
Evaluation of limit at a point and infinity, continuity. & 2 \\
Derivatives of algebraic and trigonometric functions. & 3,4 \\
Maxima and minima, engineering applications of derivatives. & 5,6 \\
The definite and indefinite integrals and their applications. & 7,8 \\
Integration by parts, integration using powers of trigonometric functions. & 10 \\
Integration using trigonometric substitution. & 11 \\
Integration by partial fractions. & 12 \\
Integration of improper integrals. & 13 \\
Transcendental functions. & 14 \\
\hline Total & 14 \\
\hline
\end{tabular}

Table 2. The mathematics achievement exam

\begin{tabular}{|c|c|c|c|c|c|}
\hline Topics & $\begin{array}{c}\text { No. of } \\
\text { lectures }\end{array}$ & $\begin{array}{c}\text { Relative } \\
\text { weight of } \\
\text { topics }\end{array}$ & $\begin{array}{c}\text { Lower } \\
\text { thinking } \\
\text { questions }\end{array}$ & $\begin{array}{c}\text { Higher } \\
\text { thinking } \\
\text { questions }\end{array}$ & $\begin{array}{c}\text { Total } \\
\text { questions }\end{array}$ \\
\hline Functions limits, theorems about limits. & 3 & 0.094 & 1 & 0 & 1 \\
\hline Evaluation of limit at a point and infinity, continuity. & 3 & 0.094 & 1 & 1 & 2 \\
\hline Derivatives of algebraic and trigonometric functions. & 6 & 0.188 & 2 & 1 & 3 \\
\hline Maxima and minima, engineering applications of derivatives. & 3 & 0.094 & 2 & 1 & 3 \\
\hline The definite and indefinite integrals and their applications. & 3 & 0.094 & 2 & 1 & 3 \\
\hline $\begin{array}{l}\text { Integration by parts, integration using powers of trigonometric } \\
\text { functions. }\end{array}$ & 3 & 0.094 & 1 & 1 & 2 \\
\hline Integration using trigonometric substitution. & 3 & 0.094 & 1 & 1 & 2 \\
\hline Integration by partial fractions. & 3 & 0.094 & 0 & 1 & 1 \\
\hline Integration of improper integrals. & 3 & 0.094 & 1 & 1 & 2 \\
\hline Transcendental functions. & 2 & 0.063 & 1 & 0 & 1 \\
\hline Total & 32 & 1.000 & 12 & 8 & 20 \\
\hline
\end{tabular}

learning. During the first term of the 2019/2020 scholastic year, the two groups studied the same topics through 14 weeks. The teaching topics are shown in Table 1.

\section{Instrumentation}

The investigators analyzed prior literature and studies pertaining to the study, such as the studies of Fazal and Bryant (2019) and Manguire (2005). Therefore, this study's data depends mainly on the post-test achievement examination, which is detailed in the following section.

\section{Achievement test design}

The researchers formulated the achievement exam to explore the effect of blended learning on student achievement in the mathematics course (MTH121). The exam was designed in line with Bloom's cognitive domain taxonomy (Birlik, 2015; Brady, 2005; Hyder \& Bhamani, 2016). Furthermore, a specification table for this examination was designed (see Table 2). The examination consisted, in its finished product, of 20 multiple-choice questions. The question element earned one mark for a correct response and zero for a wrong response. The highest possible test score was 20 , and the test duration was 60 minutes.

\section{Validity and reliability of the achievement test}

The achievement examination was verified by presenting it, in its original form, as a valid virtual examination method, to members of the teaching staff at universities whose doctoral and master's degree holders have specializations in curricula and teaching methods. In response to suggestions, some questions were removed, and others introduced, as recommended, producing a valid examination. In addition, the testretest method was applied to check the reliability of the achievement examination. The value of the Pearson's correlation coefficient was 0.801 , which is considered sufficient for this study's purpose.

\section{Equivalence of experimental and control groups (Pre- test)}

To check the equivalence of participants between the students of the two groups studied, the researchers used a T-test to compare the results of the pre-test of the topics of the mathematics course (MTH121), before implementing the blended learning, as seen in Tables 3 and 4 .

As presented in Table 4, given that the $p$ (0.063) extracted is greater than 0.05 , the test is not significant at a scale of 0.05 . This proves that there is no significant variation between the two study groups. Moreover, 
Table 3. Means and standard deviations of pre-test scores for two groups

\begin{tabular}{llcc}
\hline Group & $\mathrm{N}$ & Mean & Std deviation (SD) \\
\hline Pre-test experimental & 99 & 12.61 & 1.749 \\
Pre-test control & 97 & 12.20 & 1.288 \\
\hline
\end{tabular}

Table 4. T-test of pre-test results of the two study groups

\begin{tabular}{lcccccc}
\hline & \multicolumn{2}{c}{ Levene's Test } & \multicolumn{3}{c}{ T-test } \\
\hline & $\mathrm{F}$ & $\mathrm{Sig}$. & $\mathrm{t}$ & $\mathrm{df}$ & Sig. (2-tailed) & Mean Difference \\
\hline Equal variances assumed & 2.543 & 0.112 & 1.867 & 194 & 0.063 & 0.4102 \\
\hline Equal variances not assumed & & & 1.872 & 180.190 & 0.063 & 0.4102 \\
\hline
\end{tabular}

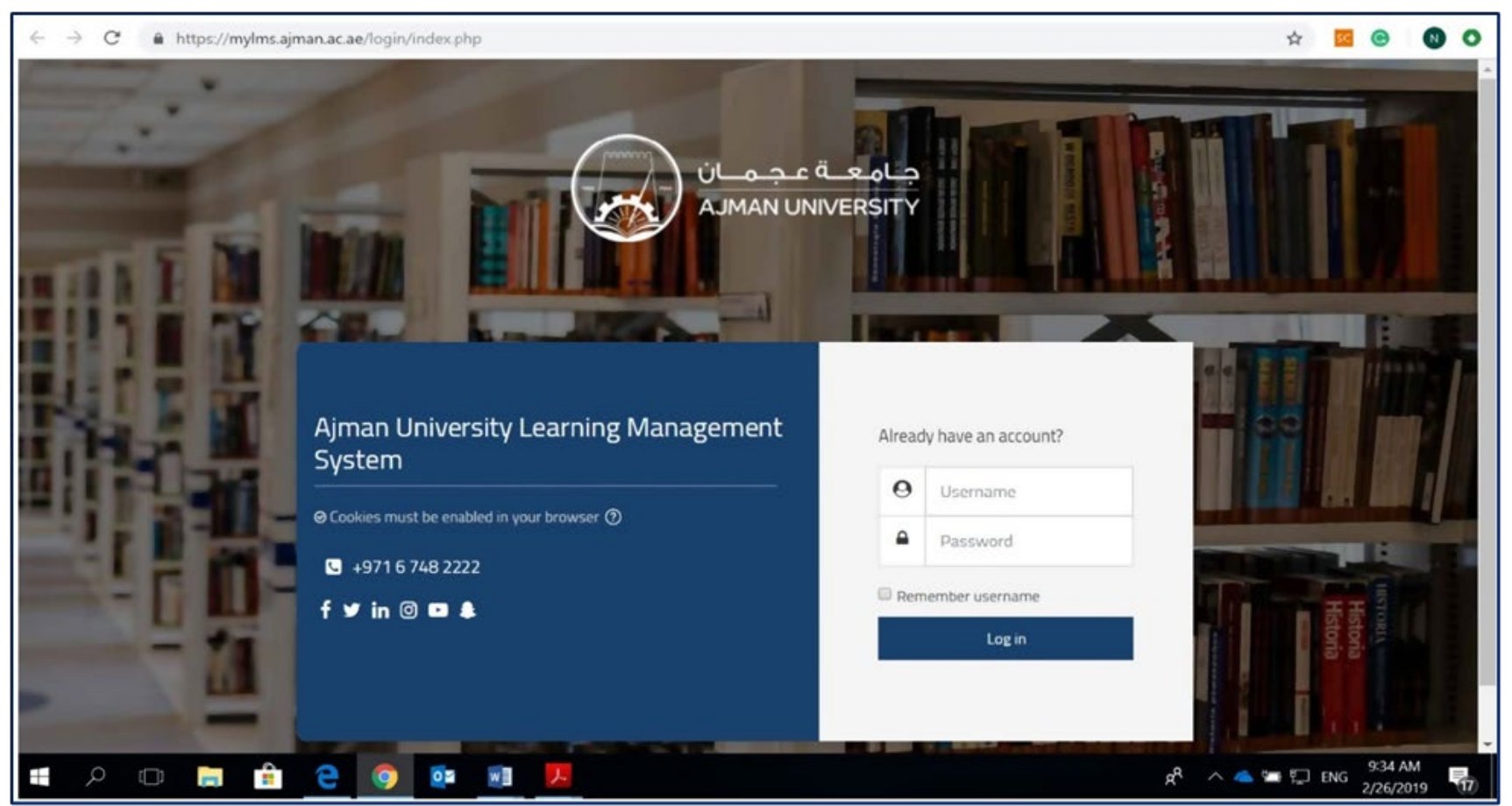

Figure 4. Homepage of Ajman University's Learning Management System website

Table 3 shows that the mean of the two groups is nearly the same value (experimental $=12.61$; control $=12.20$ ) This indicates that the experimental group and the control group were sufficiently similar before the implementation of the quasi-experimental method to ensure reliable comparison.

\section{Preparing the Educational Mathematics Course Material}

The authors organized learning activities and PPT presentations for the teaching of the mathematics (MTH121) course using blended learning. In addition, related multimedia, tasks, and pop quizzes were available on the course's digital platform, Model of Learning, to which members of the experimental group were given access. The researchers taught the experimental group students how to access and use the educational materials in the Model of Learning system. All experiment group students could log in to the Model of Learning system by supplying the required details (account and passwords) (see Figure 4). The same topics were taught to the control group using conventional learning.

The screen for the digital platform for the blended delivery of the mathematics course can be seen in Figure 5. For example, it provides explanations of the topic limits of functions, theorems about limits, and resources related to this topic of the mathematics course. Experimental group students were very engaged, showed increased motivation, and critical video reviews were submitted.

\section{Delimitations of the Study}

The delimitations for this study included Ajman University - main campus, Ajman, UAE, as a location limit, the first term of the academic year 2019/2020 as a time limit, and the students of the Engineering College at Ajman University as a human limit.

\section{Statistical Processing Methods}

The investigators used the SPSS software program to analyze the study data. First, a descriptive analysis was carried out, involving calculations such as frequency, 


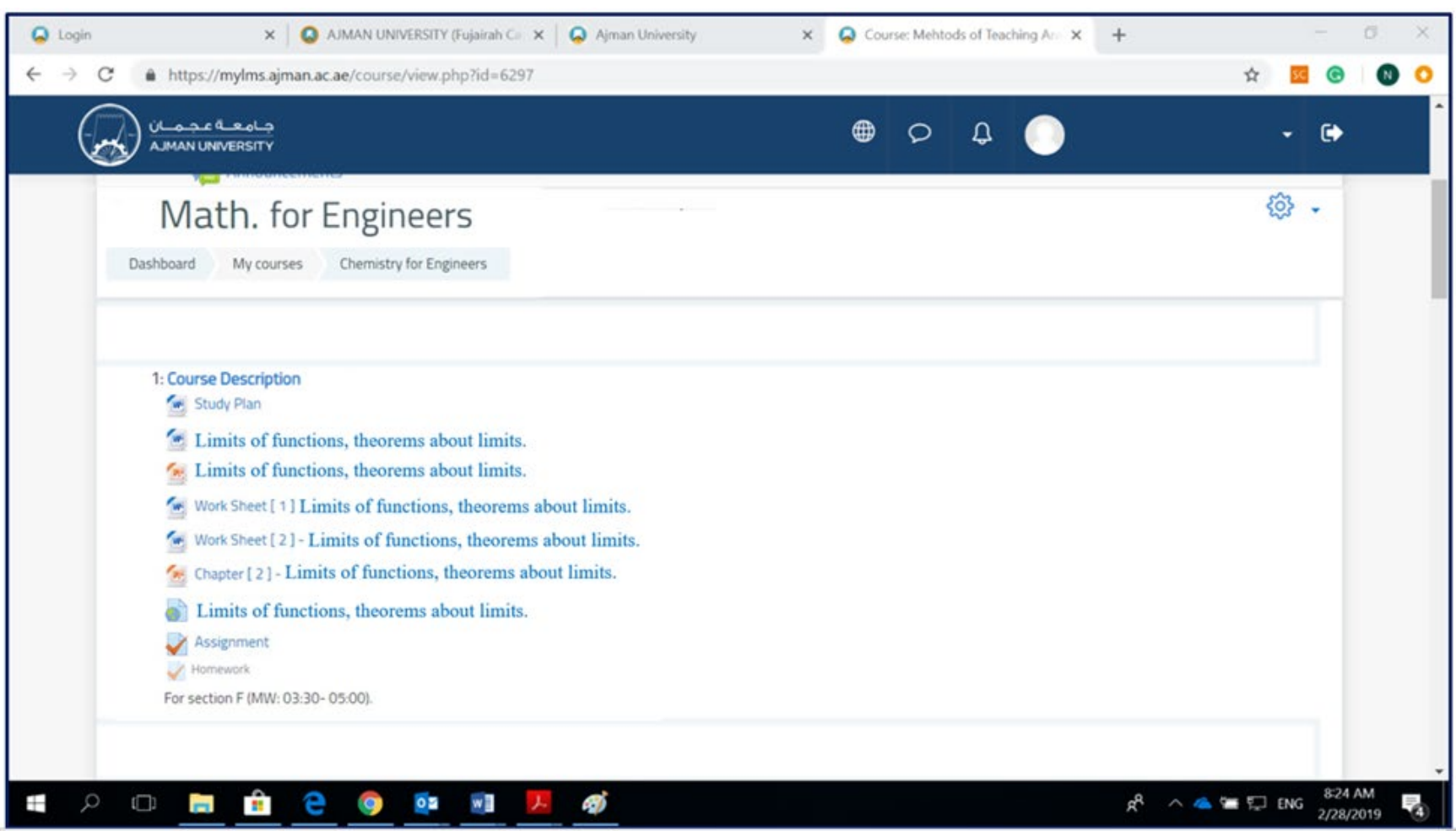

Figure 5. Course screen

Table 5. Means and SD of post-test results

\begin{tabular}{llll}
\hline Group & N & Mean & SD \\
\hline Post-test experimental & 99 & 16.87 & 2.10 \\
Post-test control & 97 & 12.74 & 1.89 \\
\hline
\end{tabular}

Table 6. The independent sample T-test of post-test data

\begin{tabular}{lcccccc}
\hline & \multicolumn{2}{c}{ Levene's Test } & \multicolumn{3}{c}{ T-test } \\
\hline & $\mathrm{F}$ & Sig. & $\mathrm{t}$ & $\mathrm{df}$ & Sig. (2-tailed) & Mean Difference \\
\hline Equal variances assumed & 3.334 & 0.069 & 16.042 & 244 & 0.000 & 4.1272 \\
Equal variances not assumed & & & 15.726 & 195.629 & 0.000 & 4.1272 \\
\hline
\end{tabular}

average, and standard deviation (SD), including independent sample test (T-test). In addition, one-way ANOVA and Scheffe tests were also carried out.

\section{FINDINGS}

\section{Study Findings Regarding RQ1}

RQ1 was "Is there a significant difference between the control group and experimental group students' mean scores on the post-test focusing on the mathematics course topics that they learned?" The variance between the experimental and control groups was calculated. In addition, a T-test was used for two independent samples, as presented in Tables 5 and 6 .

As seen in Table 5, the results indicate that the students who used blended learning demonstrated a better achievement on the post-test of the topics of the mathematics course. The experimental group grades were higher $(\mathrm{M}=16.87, \mathrm{SD}=2.10)$ than those of the control group $(\mathrm{M}=12.74, \mathrm{SD}=1.89)$.
As shown in Table 6, given that the p-value $(0.000)$ is lower than 0.05 , this confirms that there are important variations at the level of significance of 0.05 , which indicates that there is significant variance between the two groups of participants, in favor of the students of the experimental group. This indicates the positive impact of blended learning.

\section{Study Findings Regarding RQ2}

RQ2 was "Does the academic achievement of experimental group students vary by gender, students' academic evaluation (GPA), and computer skills?" To answer this question, average scores and standard deviations were computed, T-test and one-way ANOVA tests were used, and Scheffe tests were carried out to determine the significance of average differences.

\section{Gender Variable}

T-test was used to assess the significance of the differences among the mean scores of experimental group students according to gender, as indicated in 
Table 7. Means and standard deviations: gender

\begin{tabular}{lcccccc}
\hline Gender & $\mathrm{N}$ & Mean & SD & df & T. Value & Sig. (tailed) \\
Female & 50 & 16.88 & 2.03 & 97 & \multirow{2}{*}{0.054} & \multirow{2}{*}{0.957} \\
Male & 49 & 16.86 & 2.21 & 95.927 & & \\
\hline
\end{tabular}

Table 8. ANOVA test: student academic evaluation GPA

\begin{tabular}{llccccc}
\hline & & Sum of squares & df & Mean square & F & Sig. (tailed) \\
\hline GPA variable & Between groups & 101.725 & 3 & 33.908 & & \\
& Within groups & 333.568 & 95 & 3.511 & 9.657 & 0.000 \\
& Total & 435.293 & 98 & & & \\
\hline
\end{tabular}

Table 9. Scheffe test: academic evaluation (GPA)

\begin{tabular}{llccc}
\hline (I) GPA & (J) GPA & Mean Difference (I-J) & Std. Error & Sig. \\
\hline 2-less than 2.5 & 2.5-less than 3 & $-2.037-^{*}$ & .565 & .007 \\
& 3-less than 3.5 & -1.315 & .596 & .696 \\
\hline 3.5-4 & $-3.581-^{*}$ & .565 & .000 \\
\hline 2-less than 3 & 3-less than 3.5 & $2.037^{*}$ & .455 & .007 \\
& 3.5-4 & .722 & .580 & .474 \\
& 2-less than 2.5 & -1.544 & .596 & .076 \\
\hline 3.5-4 & 2.5-less than 3 & 1.315 & .455 & .474 \\
& 3.5-4 & -.722 & .610 & .005 \\
\hline
\end{tabular}

*. The mean difference is significant at the 0.05 level

Table 10. One-way ANOVA test: computer skills

\begin{tabular}{lcccccc}
\hline & & Sum of squares & df & Mean square & F & Sig. (tailed) \\
\hline Computer skills & Between groups & 68.310 & 3 & 22.770 & & \\
variable & Within groups & 366.983 & 95 & 3.863 & 5.894 & 0.001 \\
& Total & 435.293 & 98 & & & \\
\hline
\end{tabular}

Table 7. The findings illustrate that the observed $\mathrm{p}(0$. 957 ) is greater than 0.05 . Thus, the test is not significant at a level of significance of 0.05 , suggesting that there is no significant difference between the mean values for males and females in the experimental group.

\section{Academic Evaluation (GPA) Variable}

The findings of the one-way ANOVA test of students' performance according to academic evaluation (GPA) are shown in Table 8. As presented in Table 8, the findings illustrate that there are statistically significant differences in the academic achievement of experimental group students according to the variable of academic evaluation (GPA), given that $p$ is 0.00 , and thus lower than the statistical significance level needed (0.05). Therefore, in order to identify the origin of the differences, the Scheffe test was used for the next comparisons (see Table 9).

The results in Table 9 indicate that the origin of the variations according to academic evaluation (GPA) originated from students who had GPA 3.5-4.

\section{Computer Skills Variable}

The findings of the one-way ANOVA test of students' answers according to this variable are shown in Table 10. The findings clearly illustrate that there are no statistically significant differences in the academic achievement according to the variable of computer skills, given that $\mathrm{p}$ is 0.001 , which is less than the level of statistical significance required (0.05). Therefore, the Scheffe test was used to identify the origin of the differences, and the findings are shown in Table 11.

The findings shown in Table 11 indicate that the origin of the variations according to computer skills arose from students who have excellent computer skills.

\section{DISCUSSION}

The findings obtained in regards to the first study question, about whether there is a significant difference in the post-test mean score between the control group and the experimental group in their academic achievement of the mathematics course topics they studied, indicated that there was a significant difference between the students in the experimental and control groups in the study, in favor of students of the experimental group who studied using blended 
Table 11. Scheffe test: computer skills

\begin{tabular}{|c|c|c|c|c|}
\hline (I) Computer Skills & (J) Computer Skills & Mean Difference (I-J) & Std. Error & Sig. \\
\hline \multirow[t]{3}{*}{ Weak } & Moderate & -.829 & .543 & .509 \\
\hline & Good & -.179 & .567 & .992 \\
\hline & Excellent & $-2.524-^{*}$ & .664 & .004 \\
\hline \multirow[t]{3}{*}{ Moderate } & Weak & .829 & .543 & .509 \\
\hline & Good & .650 & .498 & .638 \\
\hline & Excellent & -1.695 & .607 & .056 \\
\hline \multirow[t]{3}{*}{ Good } & Weak & .179 & .567 & .992 \\
\hline & Moderate & -.650 & .498 & .638 \\
\hline & Excellent & $-2.345-^{*}$ & .629 & .005 \\
\hline \multirow[t]{3}{*}{ Excellent } & Weak & $2.524^{*}$ & .664 & .004 \\
\hline & Moderate & 1.695 & .607 & .056 \\
\hline & Good & $2.345^{*}$ & .629 & .005 \\
\hline
\end{tabular}

*. The mean difference is significant at the 0.05 level

learning. The average student score in the experimental group using blended learning was 16.87, compared to 12.74 for control group students who did not use blended learning and studied using conventional learning, as indicated in Table 5. This means that the academic achievement for the students of the experimental group who studied by using blended learning was better than that of students of the control group who studied via conventional learning. In addition, as shown in Table 6 , since the obtained p-value $(0.000)$ is less than 0.05 , this implies that there are significant differences at the level of significance of 0.05 , which confirms that there is a significant difference between the two groups of students in their understanding of the mathematics course topics. This indicates that using blended learning had a positive impact on the experimental group students' academic achievement through their more in-depth understanding of the mathematics course topics that they learned.

These results could be attributed to the positive features of a blended learning application in the teaching process, such as its flexibility, promotion of student efficiency, meeting of students' needs, building of engagement, and taking into account individual differences between students. Furthermore, Eryilmaz (2015) refer to the fact that, during blended learning, students can view and stop the lesson repeatedly at different times and periods, which means that students have time flexibility during their learning. Also, as Seage and Türegün (2020) pointed out, classroom activities and interaction with content and the teacher through blended learning also motivate and encourage students to think about content more deeply, which gives them a better understanding of the topics of the academic content.

In addition, the higher mean achievement of the experimental group of students compared to the control group of students may be attributed to the fact that blended learning enabled students to interact directly in the classroom through the use of new interaction processes, such as the internet and computers, the use of multimedia, and websites related to the topics of the lesson. This explanation is confirmed in previous studies (Alsalhi, Eltahir, \& Al-Qatawneh, 2019; Al-Qatawneh, Eltahir, \& Alsalhi, 2020; Ameloot \& Schellens, 2018; Dziuban et al., 2018; Eryilmaz, 2015; Fazal \& Bryant, 2019; Graham, 2013; Kintu et al., 2017; Sahni, 2019). The results of these studies reported that blended learning provides educational experiences closer to reality, and facilitates an interactive environment that makes students more active and interactive in the educational process. Such contributions imply that blended learning provides more effective learning outcome gains by enriching today's learning environments with developing web technologies.

The results of this study are consistent with the results of previous studies that have supported the significant impact of blended learning in the improvement of the achievement of the students and indicated the significance of blended learning in increasing motivations, and positive trends for learning topics content. The results of such previous studies also indicated that blended learning made students more motivated to learn, and correlated with positive trends towards learning. For example, Ceylan and Kesici (2017) aimed to investigate the effects of blended learning on students' academic achievement in middle schools in the southwest part of Turkey. Their results revealed that the blended learning environment correlated with significant improvements in students' achievement. Fazal and Bryant (2019) explored the effects of blended learning, specifically using the station rotation model, on the math achievement of students. Their findings showed that students instructed through blended learning scored higher on the mathematics assessment than students instructed solely in a face-to-face environment. Also, Kazu and Demirkol (2014) aimed to analyze students' academic performance by comparing the blended learning environment and the traditional learning environment of biology courses. The findings showed, on the basis of the averages of the post-test 
grades, that the experimental, blended learning students were more successful than the control group, conventional instruction students. Likewise, Al-Madani (2015) aimed to examine the effectiveness of the blended learning approach in fourth grade students' achievement in Arabic language and the development of their creative thinking. The results revealed that, based on the average scores of the post-test, the experimental group of students was more successful than the control group of students. Seage and Türegün (2020) aimed to determine the effects of traditional science instruction and blended learning on STEM achievement of elementary school students from low socioeconomic areas. The findings revealed that the instructing method had a statistically significant effect on the linear combination of the science, technology, mathematics, and engineering scores, for the benefit of the blended learning approach. Moreover, Hinampas et al. (2018) aimed to explore the influences of blended learning pedagogy on junior high school student learning achievement and the students' attitudes toward mathematics. The findings indicated that those students exposed to blended learning improved their academic achievement from pre-test to post-test to a greater degree than those students not exposed to blended learning. The practical skills manifested by students were interpreting, communicating, designing, recording, analyzing, and questioning. Additionally, Y1lmaz and Orhan (2010) aimed to measure the effectiveness of a blended learning environment at Atilim University, which was laid out on the basis of the combination of face-to-face and online environments. The findings revealed that students indicated that they learn more effectively in a blended learning environment.

The second research question explored whether the academic achievement of experimental group learners varied by gender, academic level (GPA), and computer skills. Our findings (illustrated in Tables 7-11) showed that students of the experimental group varied according to the variable of academic level (GPA), to the benefit of those students with a GPA 3.5-4, and according to computer skills, to the benefit of those students with excellent computer skills. However, there are no important variances in students' achievement based on the students' gender. This result is consistent with a study conducted by Selim (2007) that aimed to investigate the effectiveness of a blended learning environment by analyzing the relationship between student characteristics/background, design features, and learning outcomes. The findings revealed that students expressed that they learn more effectively in a blended learning environment. The results indicate that some of the student characteristics/backgrounds, such as computer skills and GPA, are significant predictors for student learning outcomes in blended learning. Moreover, Lin et al. (2017) aimed to explore the influences of blended learning pedagogy on junior high school student learning achievement and the students' attitudes toward mathematics. The findings indicated that male students and high-ability students were more motivated in the blended learning environment. Students gave positive feedback on the use of the Moodle digital learning platform for mathematics after experiencing blended learning.

Nevertheless, the findings of the study were not consistent with some studies, such as the findings of the study conducted by Yusoff, Yusoff, and Md Noh, (2017) about the impact of blended learning on the academic achievement of students on mathematics and science courses. The results of this study indicated that the posttest scores did not indicate a significant difference between the experimental and control groups. In addition, the findings of Kwak, Menezes, and Sherwood (2015) revealed that blended learning has no effect on student achievement if learning is non-cumulative and only affects student performance on assessments associated with the blended learning materials.

However, some limitations should be acknowledged. The first of these is the inability to increase student participation in both control and experimental groups due to the fact that only 196 students were enrolled in the mathematics course. Second, the investigators used the T-test and one-way ANOVA tests to explore if academic achievement varied by gender, students' academic evaluation (GPA), and computer skills for experimental group students that learned through blended learning, but did not apply it to the control group of students, because they studied through traditional learning (non-blended learning).

\section{CONCLUSION AND IMPLICATIONS}

The level of quality of education has become an essential criterion for the progress and growth of nations and societies around the world. Thus, the higher education institutions in the UAE are currently interested in developing learning strategies, techniques, and practices for the merging of information technology (IT) into processes of learning, teaching, and instruction systems. The expansion of the use of IT, e-learning, and blended learning and its models in the learning and instruction system is one of the most essential goals in higher education institutions in the UAE. This study seeks to examine the impact of using blended learning on students' achievement in the mathematics course MATH121 at Ajman University.

The findings of this research paper revealed that blended learning had a positive impact on increasing students' academic achievement in mathematics course topics. Statistical differences between the experimental and the control groups showed that the experimental group, who were taught using blended learning, achieved better results than the control group on assessments focusing on the taught content. Our 
findings also indicate that the students of the experimental group varied according to the variable of academic level (GPA), to the benefit of those students with GPA 3.5-4, and according to the variable computer skills, to the benefit of those students who have excellent computer skills. No important variances were found according to the variable of students' gender.

The findings of this research pose some significant educational implications for future research on the impact of blended learning on students' achievement. First, the findings of this study could provide insights to encourage the development and improvement of educational multimedia tools used in processes of blended learning. Second, the findings highlight the importance of further quasi-experimental and descriptive studies to explore the merits and challenges of implementing blended learning in higher education institutions more broadly. Third, the findings of this study suggest that using an online model through a blended learning approach can promote, motivate, engage, and involve students' active learning, and facilitate their construction of knowledge rather than simply passively taking in information. Fourth, modern studies are required that are specifically linked to effective environments in which blended learning can be used in higher education institutions, in order to improve academic achievement and motivation in the learning and instruction process. Finally, the study has shown that blended learning can provide students with the opportunity to learn independently, which broadens their learning and knowledge in the courses' content, such as increasing their knowledge of mathematics course topics beyond the knowledge they can obtain in the traditional classroom.

Author contributions: All authors were involved in research design, implementation of the study, data gathering, data analysis, and writing of the manuscript. All authors approve the submission of the manuscript for publication consideration. All authors read and approved the final manuscript.

Funding: This research received no specific grant from any funding agency in the public, commercial, or not-for-profit sectors.

Declaration of interest: The authors declared that they have no competing interests.

Acknowledgements: The authors would like to thank Ajman University for their cooperation and the Dean of Scientific Research for his guidance and mentorship

\section{REFERENCES}

Abouchedid, K. \& Eid, G. M. (2004). E-learning challenges in the Arab world: revelations from case study profile. Quality Assurance in Education, 12(1), $15-27$.

https://doi.org/10.1108/09684880410517405

Adiguzel, T., Kamit, T., \& Ertas, B. (2020). Teaching and Learning Experiences with Enhanced Books in Engineering Math and Science Courses. Contemporary Educational Technology, 11(2), 143-158. https:// doi.org/10.30935/cet. 660725

Alammary, A., Sheard, J., \& Carbone, A. (2014). Blended learning in higher education: Three different design approaches. Australasian Journal of Educational Technology, 30(4), 440-454. https://doi.org/ 10.14742 /ajet.693

Al-Madani, F. (2015). The effectiveness of blended learning on students' academic achievement in Arabic language and the development of their creative thinking. Asian Journal of Educational Research and Technology, 5(2), 30-37. http://www.tspmt.com/july2015_issue_part_1/5. Al-Madani.Saudi\%20Arebia.30-37.pdf

Almaiah, M. A., Al-Khasawneh, A., \& Althunibat, A. (2020). Exploring the critical challenges and factors influencing the E-learning system usage during COVID-19 pandemic. Education and Information Technologies, 25(1), 5261-5280. https:/ / doi.org/10.1007/s10639-020-10219-y

Al-Qatawneh, S., Eltahir, M., \& Alsalhi, N. (2020). The effect of blended learning on the achievement of HDE students in the methods of teaching Arabic language course and their attitudes towards its use at Ajman University: A case study. Education and Information Technologies. 3(1), 2020. https:/ / doi.org/10.1007/s10639-019-10046-w

Alsalhi, N., Eltahir, M., \& Al-Qatawneh, S. (2019). The effect of blended learning on the achievement of ninth grade students in science and their attitudes towards its use. Heliyon, 5(9), e02424. https:/ / doi.org/10.1016/j.heliyon.2019.e02424

Alzahrani, M. G., \& O'Toole, J. M. (2017). The impact of internet experience and attitude on student preference for blended learning. Journal of Curriculum and Teaching, 6(1), 65-78. https:/ / doi.org/10.5430/jct.v6n1p65

Ameloot, E., \& Schellens, T. (2018). Student teachers' perceptions of using learning analytics in a blended learning context. Proceedings of INTED2018 Conference, Valencia, Spain. https:// doi.org/10.21125/inted.2018.0879

Awodeyi, A. F., Akpan, E. T., \& Udo, I. J. (2014). Enhancing teaching and learning of mathematics: Adoption of blended learning pedagogy in University of Uyo. International Journal of Science and Research, 3(11), 40-45. https://www.ijsr.net/ archive/v3i11/T0NUMTQ2Njc=.pdf

Ayse, K. O. K. (2008). An online social constructivist tool: A secondary school experience in the developing world. Turkish Online Journal of Distance Education, 9(7), 87-98. https://doi.org/10.17718/TOJDE. 17610

Bervell, B., Nyagorme, P., \& Arkorful, V. (2020). LMSEnabled Blended Learning Use Intentions among 
Distance Education Tutors: Examining the Mediation Role of Attitude Based on TechnologyRelated Stimulus-Response Theoretical Framework. Contemporary Educational Technology, 12(2), ep273. https://doi.org/10.30935/cedtech/ 8317

Birlik, S. (2015). Taxonomy of the cognitive domain: An example of architectural education program. Procedia - Social and Behavioral Sciences, 174(4), 32723277. https:/ / doi.org/10.1016/j.sbspro.2015.01.993

Brady, A. (2005). Assessment of learning with multiplechoice questions. Nurse Education in Practice, 5(4), 238-242.

https:// doi.org/10.1016/j.nepr.2004.12.005

Bunatovich, U., \& Khidayevich, D. (2020). The importance of modern innovative teaching methods in the higher education system of Uzbekistan. Journal of Critical Reviews, 7(7), 10641067. https://doi.org/10.31838/jcr.07.07.194

Ceylan, V., \& A. E. Kesici. (2017). Effect of blended learning to academic achievement. Journal of Human Sciences, 14(1), 309-319. https://doi.org/10.14687/ jhs.v14i1.4141

Crawford, R., \& Jenkins, L. (2017). Blended learning and team teaching: Adapting pedagogy in response to the changing digital tertiary environment. Australasian Journal of Educational Technology, 33(2), 51-72. https:/ / doi.org/10.14742/ajet.2924

David, M. (2016). Situational leadership theory as a foundation for a blended learning framework. Journal of Education and Practice, 7(1), 25-30. https:/ / files.eric.ed.gov/fulltext/EJ1099593.pdf

Davis, M. H. (2003). Outcome based education. Journal of Veterinary Medical Education, 30(3), 227-232. https:// doi.org/10.3138/jvme.30.3.258

Devlin, M. \& Samarawickrema, G. (2010). The criteria of effective teaching in a changing higher education context. Higher Education Research $\mathcal{E}$ Development, 29(2), 111-124. https:// doi.org/10.1080/072943609 03244398

Dziuban, C., Graham, C. R., Moskal, P. D., Norberg, A., \& Sicilia, N. (2018). Blended learning: the new normal and emerging technologies. International Journal of Educational Technology in Higher Education, 15(3), Article 3. https://doi.org/10.1186/s41239017-0087-5

Elfaki, N., Abdulraheem, I., \& Abdulrahim, R. (2019). Impact of e-learning vs traditional learning on student's performance and attitude. International Journal of Medical Research and Health Sciences, 8(10), 76-82. https://www.semanticscholar.org/paper/ Impact-of-E-Learning-vs-Traditional-Learning-onand-Elfaki-Abdulraheem/b1252c64fc2518731b2434 fae8f5b0540a8a 8 a21
ElSayary, A. (2021). Using a Reflective Practice Model to Teach STEM Education in a Blended Learning Environment. Eurasia Journal of Mathematics, Science and Technology Education, 17(2), em1942. https:/ / doi.org/10.29333/ejmste/9699

Epstein, R. M. (2007). Assessment in medical education. New England Journal of Medicine, 356(4), 387-396. https:/ / doi.org/10.1056/NEJMra054784

Eryilmaz, M. (2015). The Effectiveness of blended learning environments. Contemporary Issues in Education Research, 8(4), 251-256. https:// doi.org/10.19030/cier.v8i4.9433

Fazal, M., \& Bryant, M. (2019). Blended learning in middle school math: The question of effectiveness. Journal of Online Learning Research, 5(1), 49-64. https:/ / eric.ed.gov/?id=EJ1208816

Fitzsimons, M. (2014). Engaging students' learning through active learning. Irish Journal of Academic Practice, 3(1), 1-26. https://doi.org/10.21427/ D7842T

Francis, R. \& Shannon, S. J. (2013). Engaging with blended learning to improve students' learning outcomes. European Journal of Engineering Education, 38(4), 359-369. https:// doi.org/10.1080/03043797. 2013.766679

Graham, C. R. (2013). Emerging practice and research in blended learning. In M. G. Moore (Ed.), Handbook of distance education (3rd ed., pp. 333-350). Routledge.

Hinampas, R., Murillo, C., Tan, D., \& Layosa, R. (2018). Blended learning approach: Effect on students' academic achievement and practical skills in science laboratories. International Journal of Scientific and Technology Research, 7(11), 63-69. https://www.researchgate.net/publication/32903 2833_Blended_Learning_Approach_Effect_On_Stu dents'_Academic_Achievement_And_Practical_Sk ills_In_Science_Laboratories

Huang, H. (2002). Toward constructivism for adult learners in online learning environments. British Journal of Educational Technology, 33(1), 27-38. https:// doi.org/10.1111/1467-8535.00236

Kazu, I., \& Demirkol, M., (2014). Effect of blended learning environment on high school students' academic achievement. Turkish Online J. Educ. Technol, 13(1), 78-87. https://eric.ed.gov/ ?id=EJ1018177

Kemp, L. (2013). Introducing blended learning: An experience of uncertainty for students in the United Arab Emirates. Research in Learning Technology, 21(1), Article 18461. https://doi.org/10.3402/ rlt.v21i0.18461

Kintu, M. J., Zhu, C., \& Kagambe, E. (2017). Blended learning effectiveness: The relationship between student characteristics, design features and outcomes. International Journal of Educational 
Technology in Higher Education, 14(7), 1-20. https:/ / doi.org/10.1186/s41239-017-0043-4

Klimova, B. (2017, September). Evaluation of the blended learning approach in the course of business English: A case study. In International Symposium on Emerging Technologies for Education (pp. 326-335). Springer, Cham. https://doi.org/10.1007/978-3319-71084-6_37

Kwak, D., Menezes, F., \& Sherwood, C. (2015). Assessing the impact of blended learning on student performance. Economic Record, 19(292), 91-106. https:/ / doi.org/10.1111/1475-4932.12155

Lin, Y., Tseng, C., \& Chiang, P. (2017). The effect of blended learning in mathematics course. Eurasia Journal of Mathematics, Science and Technology Education, 13(3), 741-770. https://doi.org/10.12973 / eurasia.2017.00641a

Malik, R. (2018). Educational challenges in 21st century and sustainable development. Journal of Sustainable Development Education and Research, 2(1), 9-20. https:/ / doi.org/10.17509/jsder.v2i1.12266

Manguire, K. (2005). Professional development in blended elearning environment for middle school mathematics teachers (M.A. dissertation). University of Toronto, Canada.

Marina, D., \& Tatjana, G. (2020). Teachers' assessment of active learning in teaching Nature and Society. Economic Research-Ekonomska Istraživanja, 33(1), 1265-1279. https:/ / doi.org/10.1080/1331677X.2020.1728563

Meyer, M., \& Norman, D. (2020). Changing design education for the 21st century. The Journal of Design, Economics, and Innovation, 6(1), 13-49. https:/ / doi.org/10.1016/j.sheji.2019.12.002

Mondal, G., Majumder, P., \& Mandal, M. (2019). Effect of blended learning strategy for secondary school science students. International Journal of Research and Analytical Reviews, 6(1), 381-387. http:/ /ijrar.com/ upload_issue/ijrar_issue_20542795.pdf

Moskal, P., Dziuban, C., \& Hartman, J. 2012. Blended learning: A dangerous idea? The Internet and Higher Education, 18(1), 15-23. https://doi.org/10.1016/j.iheduc.2012.12.001

Mula, J. (2015). Effects of e-blended instruction on grade 10 students' performance and attitude towards geometry (M.A. dissertation). Trece Martires City National High School.

Oweis, T. (2018). Effects of using a blended learning method on students' achievement and motivation to learn English in Jordan: A pilot case study. Education Research International, 2018(91), Article 7425924. https:/ / doi.org/10.1155/2018/7425924

Pechenkina, E., Scardamaglia, A., \& Gregory, J. (2018). "It's the Combination That Works": Evaluating Student Experiences with a Multi-element Blended
Design in First-year Law. Contemporary Educational Technology, 9(4), 405-422. https:/ / doi.org/10.30935 /cet.471019

Power, M. (2008). The emergence of a blended online learning environment. MERLOT Journal of Online Learning and Teaching, 4(4), 503-5014. https://jolt.merlot.org/vol4no4/power_1208.pdf

Rahman, M. M., Singh, M. K. M., \& Pandian, A. (2018). Exploring ESL teacher beliefs and classroom practices of CLT: A case study. International Journal of Instruction, 11(1), 295-310. https://doi.org/ 10.12973/iji.2018.11121a

Rocher, A. (2018). Active learning strategies and academic self-efficacy relate to both attentional control and attitudes towards plagiarism. Active Learning in Higher Education, 21(3), 203-216. https:/ / doi.org/10.1177/1469787418765515

Rooney, J. E. (2003). Blending learning opportunities to enhance educational programming and meetings. Association Management, 55(5), 26-32. https: / / www. scirp.org/(S(i43dyn45teexjx455qlt3d2q))/reference / ReferencesPapers.aspx?ReferenceID=2143743

Sahni, J. (2019). Does blended learning enhance student engagement? Evidence from higher education. Journal of e-Learning and Higher Education, 2019(2019), Article 121518. https:/ / doi.org/10.5171 /2019.121518

Sarıtepeci, M. \& Çakır, H. (2015). The effect of blended learning environments on students' academic achievement and student engagement: A study on social studies course. Education and Science, 40(177), 203-216. https:/ / doi.org/10.15390/EB.2015.2592

Seage, S. J., \& Türegün, M. (2020). The effects of blended learning on STEM achievement of elementary school students. International Journal of Research in Education and Science (IJRES), 6(1), 133-140. https://doi.org/10.46328/ijres.v6i1.728

Selim, H. M. (2007). Critical success factors for e-learning acceptance: Confirmatory factor models. Computers $\mathcal{E}$ Education, 49(2), 396-413. https://doi.org/ 10.1016/j.compedu.2005.09.004

Shaaruddin, J., \& Mohamad, M. (2017). Identifying the effectiveness of active learning strategies and benefits in curriculum and pedagogy course for undergraduate TESL students. Creative Education, 8(14), 2312-2324. https://doi.org/10.4236/ce.2017. 814158

Shang, F., \& Liu, C.-Y. (2018). Blended learning in medical physiology improves nursing students' study efficiency. Advances in Physiology Education, 42(4), 711-717. https://doi.org/10.1152/advan. 00021.2018

Sicilia, N. (2018). Blended learning: the new normal and emerging technologies. International Journal of Educational Technology in Higher Education, 15, 
Article 3. https://doi.org/10.1186/s41239-0170087-5

Snoussi, T. (2019). ICT faculties' usage in the UAE private universities: A case study. Global Media Journal, 17(33), 1-8. https://www.globalmedia journal.com/archive/gmj-volume-17-issue-33year-2019.html

Stuchlikova, L. (2016). Challenges of education in the 21st century. International Conference on Emerging eLearning Technologies and Applications (ICETA), Vysoke, 335-340. https:// doi.org/10.1109/ICETA. 2016.7802072

Tongchai, N. (2016). Impact of self-regulation and open learner model on learning achievement in blended learning environment. International Journal of Information and Education Technology, 6(5), 343-347. https:/ / doi.org/10.7763/IJIET. 2016.V6.711

Trapp, S. (2006). Blended learning concepts: A short overview. EC- TEL Workshops Proceedings, ISSN 1613-0073, 28-35. http://ftp.informatik.rwthaachen.de/Publications/CEUR-WS/Vol213/paper7.pdf

United Nations. (2019). The future is now: Science for achieving sustainable development. Global sustainable development report. New York: United Nations.

Ustun, A., \& Tracey, M. (2020). An effective way of designing blended learning: A three phase designbased research approach. Education and Information Technologies, 25(1), 1529-1552. https://doi.org/ 10.1007/s10639-019-09999-9

Valerie, J. (2005). The effectiveness of blended Learning for the employees (Unpublished dissertation). Fiflding Graduate University.
Velle, L. (2020). The challenges for teacher education in the 21st century: Urgency, complexity and timeliness. Journal of Education for Teaching, 46(1), 13. https:/ / doi.org/10.1080/02607476.2019.1708621

Vrazalic, L., MacGregor, R., Behl, D., \& Fitzgerald, J. (2009). E-learning barriers in the United Arab Emirates: Preliminary results from an experimental investigation. IBIMA Business Review, 4(1), Article 458727. https:/ / doi.org/10.5171/2010.458727

Wang, M. J. (2010). Online collaboration and offline interaction between students using asynchronous tools in blended learning. Australasian Journal of Educational Technology, 26(6), 830-846. https:/ / doi.org/10.14742/ajet.1045

Wright, B. M. (2017). Blended learning: Student perception of face-to-face and online EFL lessons. Indonesian Journal of Applied Linguistics, 7(1), 64- 71. https:/ / doi.org/10.17509/ijal.v7i1.6859

Yeou, M. (2016). An investigation of students' acceptance of Moodle in a blended learning setting using technology acceptance model. Journal of Educational Technology Systems, 44(3), 300-318. https:// doi.org/10.1177/0047239515618464

Yılmaz, M. B., \& Orhan, F. (2010). Pre-service English teachers in blended learning environment in respect to their learning approaches. The Turkish Online Journal of Educational Technology (TOJET), 9(1), 157-158. https://files.eric.ed.gov/fulltext/ EJ875779.pdf

Yusoff, S, Yusoff, R., \& Md Noh, N. (2017). Blended Learning Approach for Less Proficient Students. SAGE Open, 7(3), 1-8. https://doi.org/10.1177/ 2158244017723051

\section{http://www.ejmste.com}

